University for Business and Technology in Kosovo

UBT Knowledge Center

Oct 28th, 2:00 PM - 3:30 PM

\title{
The Youth, Their Viewership and Trustworthiness Towards Kosovo's Televisions
}

\author{
Ferid Selimi \\ University for Business and Technology, ferid.selimi@ubt-uni.net
}

Follow this and additional works at: https://knowledgecenter.ubt-uni.net/conference

Part of the Journalism Studies Commons

\section{Recommended Citation}

Selimi, Ferid, "The Youth, Their Viewership and Trustworthiness Towards Kosovo's Televisions" (2017). UBT International Conference. 199.

https://knowledgecenter.ubt-uni.net/conference/2017/all-events/199

This Event is brought to you for free and open access by the Publication and Journals at UBT Knowledge Center. It has been accepted for inclusion in UBT International Conference by an authorized administrator of UBT Knowledge Center. For more information, please contact knowledge.center@ubt-uni.net. 


\title{
The youth, their viewership and trustworthiness towards Kosovo's Televisions
}

\author{
Ferid Selimi \\ UBT - Higher Education Institution, Lagjja Kalabria, 10000 p.n., Pristine, Kosovo \\ ferid.selimi@ubt-uni.net
}

\begin{abstract}
National and private televisions in Kosovo pay a great importance to informative programs with the aim to increase the viewership and trustworthiness of television programs. This paperwork estimates the viewership and trustworthiness of a wide range of kosovo televisions. In the framework of this paperwork is use the method of carrying out quetionnaires, where 25 young boys and girls aged betweed 19-25 have answered the respective questions. From this questionnaire it was analysed a wide range of National and private commercial televisions. It was concluded that a the vast majority of youngsters follow different informative tv channels, as well as news, interviews and docummentaries.
\end{abstract}

Key words: trustworthiness, informative program, television, viewership.

\section{Introduction}

The informing process which is carried out through the electronic Media, especially the one that concerns the visual media, is of significant importance due to the fact that enables the audience to perceive not only the words but even sounds and a visual panorama of news. The incorporation of these three components such as words, voice and visual performance provides a full-fledged informative process for the audience. There has been carried out a questionnaire, comprised of 208 youngsters with ages varying from 19-28. This questionnaire has taken place in six different regions of Kosovo. Television which was formerly considered to be one of the main means of imbibing and perceiving information is consistently losing its "supremacy". Online Media are utterly replacing television and the old approach to information. This is obviously witnessed in the questionnaire which has taken place in six regions of Kosovo; Prishtina, Gjilan, Prizren, Ferizaj, Peje, Mitrovice. The participants who were asked in the questionnaire share different point of views relating this issue. The latest technological developments have somehow suffocated the old traditional media and have and the vast majorities of youngsters have the latest brands of mobile phones and have the opportunity to acquire information and follow the ongoing developments through the phone and other up-to-date electronic devices. The number of youngsters who have a mobile phone in their pocket is becoming increasingly high and predominantly most of them have unlimited access to internet websites. There have been drawn multifaceted conclusions from this questionnaire. The participants have been asked if they had televisions at home, if they are connected through cableoriented TV Channels of IPTV, and satellite message conveying means. The participants have given a wide range of meaningful answers, this also varies from their social, cultural and intellectual backgrounds and the regions that they pertain. They are even asked what television programs they 
follow. The overall number of number of participant was about 208, from whom $64 \%$ were males, $36 \%$ females and $19 \%$ were under 19 years old. One other interviewed category approximately $14.9 \%$ were 20 years old, $11 \%$ were 22 years old and $10 \% 21$ years old. This research led us to the conclusion that the answers of the participants varied due to a broad scope of factors such as age, gender and their origin. As far as the origin is concerned, the number of youngsters from Prishtina were $46 \%$,the youngsters from Gjilan and Ferizaj were 13\%.7, 26\% from Ferizaj, and 26\% from other regions of Kosovo. It's worth mentioning that $61.5 \%$ of participants had TV at home, $37 \%$ of them have the opportunity have the opportunity to chose the favorite TV channel, while the others are obliged to submit to will of their family members. While $85.3 \%$ of them have the opportunity to follow the TV news through the digital network. Only $75 \%$ of them followed the cable-oriented TV programs, $11.3 \%$ of them had analog TV and 15.6 followed the TV programs through the IPTV satellites.

\section{Methodology}

First and foremost, to carried out a detailed and in-depth inquiry, to measure the viewership of TV programs were taken into account the opinions of youngsters aged 19-28. The method used in this inquiry is that of questionnaire-oriented one. The questionnaire is comprised of 25 questions and they are even conveyed through electronic addresses in Google. The answers have been acquired in automatically. The inquiry is filled by 208 who have different origins in six regions of Kosovo. There has been accomplished a subtle scrutiny of the outcomes.

\section{Findings -The youngsters and viewership of informative programs}

Based on the inquiry carried out by (Kosumi.B 2016:303), concerning the viewership of informative programs. According to the acquired feedback, it is concluded that the vast majority of people aged between 19-28 years old are not very keen on TV programs. Moreover, they are increasingly trying to avoid spending hours in front of TV screens. It's worth pointing out that not all of them spend share the same approach concerning the time they spend watching TV programs. It's worth emphasizing that $73.4 \%$, don't even appreciate at all watching the traditional old-fashioned TV programs, and most of them agree that TV news programs lack trustfulness. These facts witness that even in Kosovo we have to cope with a broad scope of comments when it comes to tackle this issue. These questionnaire is submitted to 208 participants from whom $31.6 \%$ watch less than one hour TV; $18.9 \%$ of them spend one hour in front of TV screens and the remaining part spend up to three hours. Approximately half of them spend time in front of TV only when they don't have any other occupations. While $43 \%$ of them watch TV only during the evening or at night. These statistics clearly mirror their common interests. For some of the participants of the questionnaire, TV is a means of relaxing themselves from the dull daily routine. However, there is a big difference in their insights when we approach to TV as the main mean of information, that keeps us updated with the latest events, developments and the most concerning issues, which are related to foreign policies and specific personalities that with their attitude may lead the world to unpredictable paths (Kovach, B 2009;35). The reason why people are not used to following the TV programs regularly, doesn't come as a result of the lack of adequate programs but from the fact that people are subject to many occupations and daily routine and don't have enough time to follow them. 


\section{The selection of TV Channels}

Indeed, to fulfill a full-fledged inquiry, it's worth emphasizing that in Kosovo operate a wide range of TV programs that which vary from national, private and commercial-oriented ones. There are three national televisions, respectively; the Kosovo Radio-television, KohaVision, and 21 RadioTelevision. almost all of them have their subsidiaries in Albania and other countries in the region. The viewership of this wide range of televisions, is as follows; TV Klan Albania is watched by $31 \%$ of the participants of young age, Klan Kosova is watched by $25 \%$ of them, RTV21 by $15 \%$; KTV by $13 \%$, whereas RTK, was followed by only $8 \%$ of the participants. (Russ-Mohl, 2010;90). This means that the young audience are mainly oriented towards the private and commercial televisions rather than the public ones. As far as the matter of informative news is concerned the national televisions are on the top of the ranking and are lined up as follows; KTV is followed by 59.6\%, RTK followed by $44.3 \%$, (it's worth emphasizing that the participants that were asked from the questionnaire had the opportunity to choose more than one TV Program). According to the acquired data, there is witness a sort of incompatibility between the percentage of persons who follow the whole programs transmitted by the Television and the ones which is very low about $8 \%$ and the ones who follow the news is $44.3 \%$, while the viewership of RTV21 is $24.6 \%$. it is concluded that even though the other national TV's tend to provide trustworthy information for the audience, they couldn't manage to attain the quality and the viewership of RTK, which is remains the main source of information. Quality is the underlying factor that people are used to watching or following the news in RTK, while the other factor is that one which is closely related to the innovative issue, $46 \%$ of participants follow news only taking into account the innovative activities provided in the respective TV's. Curiosity is also an important factor, and as matter of fact $40.9 \%$ follow the news due to this fact. It has been come up to the conclusion that TV programs are mainly followed due to the issue of curiosity rather than that of quality. They are curious to listen the news sessions. Being objective is the third essential component that attracts viewership and audience, in other words unbiased news. When news sessions are qualitative they also provide trustful information for the audience, a incorporation of these factors enables the attainment of perfection and professionalism. The assessment of news is not focused only in visual clearance, but even in fluent performance from the side of moderator. (Bergstrom 2008). It's worth mentioning that the audience must be fostered to follow the TV news sessions by driving subtitles. The outcomes of the questionnaire concerning this components are as follow; $72 \%$ of the participants have admitted watching the evening news sessions, while $32.1 \%$ have admitted watching news in different time intervals. While the morning news were followed by $7 \%$, the midday news followed by $5.9 \%$. The in-depth elaboration of this statistics has provided an important conclusion thatpeople are commonly used to seeing news during the evening. 


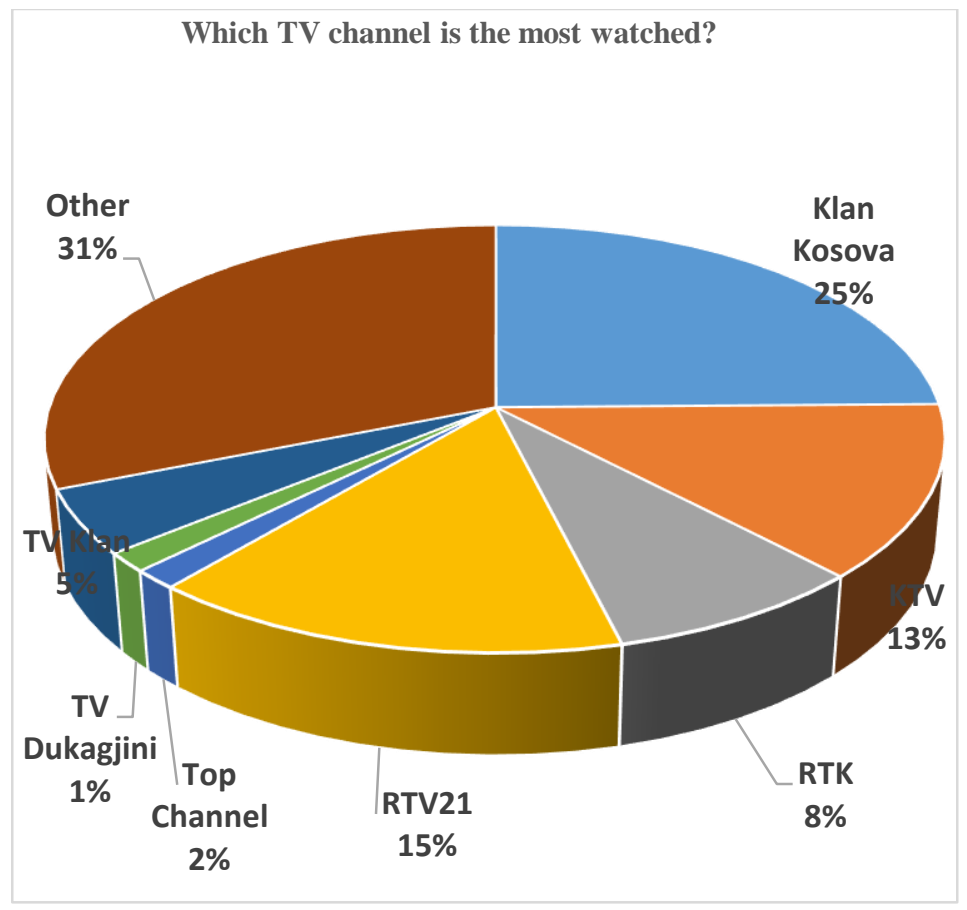

Figure 1: Graphic coverage of the most watched TV channels

\section{The transmission of informative sessions}

There is a broad scope of private and commercial TV which provide a multifaceted amalgam of informative sessions, and which are continuously followed by audience. Their content is frequently comprised of news, debates, movies, sport, documentaries, chronics, reportages, entertainment etc. (Selimi 2016). Each of them is followed in different periods of time during the day. Generally speaking the genre which evoked more audience is the one of movies with about $54 \%$, followed by news with about $37 \%$ and debates $35 \%$. Meanwhile the entertainment shows are followed by $29.6 \%$ of the participants. Documentaries have their own part of viewership, but don't seem quite preferable compared to the other genres. The TV sport programs are followed by $17 \%$ of the participants, reportages by $7.3 \%$, and chronics by $6.8 \%$, and other TV genres by $14.6 \%$. The political debates have exceeded the cultural and economic-oriented debates. The reportages are followed by $13.7 \%$, while $19.1 \%$ of the participants don't follow them at all. Meanwhile, $52 \%$ of the participants follow foreign reportages concerning global developments and $28.9 \%$ local reportages. This means that the vast majority of them follow all types of reportages wherever they come from. KTV is that sort of program that prioritizes sport and almost 193 participants $49.7 \%$ admit that has a leading role in this perspective. RTK is followed by $35.2 \%$, and RTV21 $22.3 \%$ however $52 \%$ of the 
participants think that there is enough space, whereas $47.2 \%$ think that there is not enough space for this to exploit concerning this issue.

\section{Which is the objective of the news?}

The audience asks for qualitative and valuable news resources. According to this, it is concluded that quality is one of the underlying factors that persons opt for one TV program rather than the other. The data mentioned above witnessed underscored that RTK leaded the ranking of TV's. So the news quality is closely related to the attendance of TV programs.

\section{Trustfulness of News}

Despite the fact that the young audience follows the news through the national TV's, it has been proved that they are mostly oriented towards RTK, but still the trustfulness varies. $51.7 \%$ of participants partly trust the news that listen to the TV, whereas $37.3 \%$ totally trust their content. When it comes to unbiased news $61.5 \%$ of the participants admit that the evening news are trustworthy ones. Whereas $35.4 \%$, believe or tend to have the insight that the midday news sessions are the most qualitative ones. The vast majority of participants admit that they perceive and get to know important information while following the news sessions. So $60 \%$ of them say that they imbibe new ideas and clues about the latest developments., $25.4 \%$ get to new facts and arguments about the current situations and events and only $13.9 \%$ of them think that it's waste of time watching news.

\section{Conclusions}

Being aware that providing information for the audience plays a crucial role in society, the conveyance of the informative session among young people between 19-28 years old is of significant importance, so they may enjoy the right to informed and updated with the latest developments, news and events. According to the data which were obtained in this research and the answers taken from the participants of this questionnaire we have concluded in this points:

1. The vast majority of them stay in front of TV;

2. Their interest and points of view vary from one another;

3. There is witness a sort of diversification in thoughts, insights and ideas when it comes to the issue of selecting the favorite informative sessions;

4. Most of the participants have said confessed the opportunity to chose their favorite TV channel;

5. Movies are the favorite genres;

6. The evening are the most followed sessions;

7. None of the national TV's pays enough attention to the activities related to 


\section{References}

1. Bergstrom, Bo. Bazat e komunikimit pamor. Tiranë, 2010

2. Bourdieu, Pierre. Mbi televizionin. Tiranë, 2015

3. Fuga, Artan\& Bashkim Gjergji, Gentiana Skurra, Iris Luarasi, Jonila Godole, Mark Marku. Media në demokratizim. Papirus. Tiranë, 2014

4. Kosumi, Bajram. Zhanret e gazetarisë. UBT. Prishtinë, 2016.

5. Kovach, Bill\& Tom Rosenstiel. Elemete të gazetarisë. ISHM. Tiranë, 2009

6. Russ-Mohl, Stephan. Gazetaria. Tiranë, 2010

7. Selimi, Ferid. Transmetuesi publik. Jehona. Prishtinë, 2016 